\title{
Validity of Junior High School Mathematics Textbooks to Support Mathematical Literacy Skills
}

\author{
Wardi Syafmen ${ }^{1}$, Novferma ${ }^{2}$, Febbry Romundza ${ }^{3}$, Ari Frianto ${ }^{4}$ \\ ${ }^{124}$ Jambi University \\ ${ }^{3}$ Jakarta State University \\ "Corresponding author.Email: wardisyafmen8@gmail.com
}

\begin{abstract}
Mathematical literacy is very important for the society in the 21 st century. An individual is able to see literate not only understands mathematical concepts or materials but can also apply his understanding in solving problems according to the context of the real world. However, mathematical literacy skills at junior high school level are still relatively low, this is obtained from PISA results and initial observations (field). One solution that can be done to overcome the low mathematical literacy is to design a mathematics textbook to support these literacy skills. This research aims to develop junior high school mathematics textbooks that can support mathematical literacy skills. This research is part of a development study that uses a 4-D development model. The 4-D model development stage consists of 4 steps: (1) define, (2) design, (3) develop, and (4) disseminate. This product was validated by 5 experts, namely 2 design experts, 2 material experts, and 1 instrument expert. This Research Instrument consists of a validation sheet of design experts, materials, and instruments (tests of mathematical literacy capabilities). The validator's suggestions and comments on the mathematics textbook of teaching junior high school were analyzed descriptively, while the data in the form of scores were analyzed descriptively and quantitatively. The results of this study indicate that the design validation of the first and second validators met the valid criteria of $80.53 \%$ and $81.58 \%$. The material validation of the first and second validators met the valid criteria, namely $79.31 \%$ and $80 \%$. The instrument validation also met the valid criteria of $81.82 \%$. So it can be concluded that the product in the form of junior high school mathematics textbooks meets the valid criteria and is feasible to apply
\end{abstract}

Keywords: Validity of Books, Junior High School Mathematics Textbooks, Mathematical Literacy Skills.

\section{INTRODUCTION}

Mathematics is one of a discipline which has a vital role in human life that is as service providers to develop other sciences, and also it is a subject that requires a lot of mathematical abilities. One of the capabilities of being very important to help students develop knowledge and skill mathematics is the ability of mathematical literacy.

Literacy is a set of students' understanding to recognize symbols in both individual and group development. This ability have diversity in the context of social and cultural, to meet needs, demands and education, and the idea of mathematical literacy in advanced life today means an understanding or human skill in modern life that functions effectively [1] [2]. Meanwhile, mathematical literacy is the ability of students in applying, interpreting, using, and even reasoning various contexts in everyday life [3]. An individual is able to see literate not only understands mathematical concepts or materials but can also apply his understanding in solving problems according to the context of the real world. Various contexts can be interpreted as one of them to use good language content containing basic mathematical concepts that can be understood by students in understanding, using, and solving problems [4]. Mathematical literacy is a person's ability to formulate, use and interpret mathematics in various contexts of daily life problems efficiently [5]. Mathematical literacy is not sufficient only to be able to use knowledge and understanding, but also to be able to use it effectively [6]. Mathematical literacy is knowledge to know and use basic mathematics in everyday life. In this sense, someone who has good mathematical literacy 
skills has a sensitivity to which mathematical concepts are relevant to the phenomenon or problem he is facing [7] . Mathematical literacy is the ability of students to formulate, use, and interpret mathematics in daily life. So it can be interpreted that mathematical literacy skills are very important abilities that students have in learning mathematics.

But in fact, the mathematical literacy skills of students in Indonesia are low. This is in accordance with the results of research conducted by PISA that the achievement of the mathematics score of Indonesian students on PISA in 2015 was 386, while the average mathematics score from various countries was 490. In addition, Indonesia achieved the ability at the level of 56 as much as $0.8 \%$ compared to the OECD average of $15.3 \%$ and the ability below level 2 was $42.3 \%$ compared to the OECD average of $13.0 \%$. This makes Indonesia ranked $62^{\text {nd }}$ out of 70 countries. From this fact shows that the mathematical literacy ability of students in Indonesia is still low [8]. This is consistent with the initial observation that junior high school students mostly work on closed or routine questions, compared to open or nonroutine questions that contain various contexts on each problem. In fact, mathematical literacy is more about giving questions which usually contain real life contexts on each problem.

Based on the survey results of each problems described above, it is necessary to develop literacy skills so that it can focus on the achievement of the learning objectives. To achieve the goal effectively, it requires the ability of a teacher to design or manage the learning optimally. Effective and efficient planning and implementation of learning can be arranged in the form of teaching materials. One of the teaching materials that will be developed is a textbook. The textbooks used by students currently do not support mathematical literacy skills, since the presence of a material concept is not associated with realistic situations that can be experienced or imagined by students. Moreover, there is no mathematical process that can bridge realistic mathematics problems with formal mathematics, and also does not present question exercises that are in accordance with questions of mathematical literacy skills. Therefore, students are not accustomed to solve questions that measure mathematical literacy skills, resulting in low students' mathematical literacy skills.

Based on the problems above, researchers are interested in developing junior high school mathematics learning textbooks to support students' mathematical literacy abilities. The book developed will contain nonroutine or open questions, as well as real-life contexts for each problem.

\section{METHOD}

This research is part of development research, where this development produces a product in the form of junior high school mathematics textbooks that can support mathematical literacy skills. This study uses a 4-D development model, where the development stage of a 4D model consists of 4 steps: (1) definition, (2) design, (3) development, and (4) spread (disseminate). The research instruments used were 1) design validation sheets; 2) material validation sheet; and 3) instrument validation sheet. Textbooks that have been developed are then tested for validity. The validity test was carried out by asking several experts to fill out a validity test questionnaire. The textbook was validated by 5 experts or validators, namely 2 design experts, 2 material experts and 1 instrument expert.

The validator's suggestions and comments on the mathematics textbook for teaching junior high school were analyzed descriptively, while the data in the form of scores were analyzed descriptively and quantitatively. The validity analysis useds a Likert scale with a score of 1-5. The Likert scale is a scale used to measure attitudes, opinions, etc., the following is the scoring using the Likert scale, namely:

Table 1. Scoring using a Likert Scale [9]

\begin{tabular}{|l|l|}
\hline Score & Category \\
\hline 5 & Strongly agree \\
\hline 4 & Agree \\
\hline 3 & Disagree less \\
\hline 2 & Disagree \\
\hline 1 & Strongly Disagree \\
\hline
\end{tabular}

The validity analysis aims to determine whether the mathematics learning textbook developed meets the validity criteria. The validity of textbooks was analyzed based on data obtained from the design validation questionnaire, materials and instruments. The validation result data that had been obtained were converted into qualitative data with a scale of five. The conversion on a scale of five was adapted from Widoyoko (2009: 238) as in table 1 as follows:

Table 2 Criteria for the Validity of Learning Textbooks

\begin{tabular}{|c|c|}
\hline Score Interval & Category \\
\hline$X>\bar{X}_{i}+1,8 s b_{i}$ & Very Valid \\
\hline $\bar{X}_{i}+0,6 s b_{i}<X \leq \bar{X}_{i}+1,8 s b_{i}$ & Valid \\
\hline $\bar{X}_{i}-0,6 s b_{i}<X \leq \bar{X}_{i}+0,6 s b_{i}$ & Enough \\
\hline $\bar{X}_{i}-1,8 s b_{i}<X \leq \bar{X}_{i}-0,6 s b_{i}$ & Less Valid \\
\hline$X \leq \bar{X}_{i}-1,8 s b_{i}$ & Invalid \\
\hline
\end{tabular}

Information:

$X \quad=$ Score empiris

$\bar{X}_{i} \quad=$ Ideal average $=\frac{1}{2}($ maximum ideal score

+ minimum ideal score) 
$s b_{i}=$ Ideal standard derivation $==\frac{1}{6}$ (maximum ideal score - minimum ideal score)

Maximum ideal score $=$ Number of criteria items $\mathrm{x}$ the highest score

Minimum ideal score $=$ The number of criteria item $\mathrm{x}$ the lowest score

The learning textbooks developed in this study are said to be valid if the category of each device is at least in the valid category.

\section{RESULTS AND DISCUSSION}

The validation of learning textbooks by experts aims to see the contents of the product developed before conducting the trial. Initial product validation (draft 1) was carried out by five expert lecturers, namely 2 material expert lecturers, 2 design expert lecturers, and 1 instrument expert lecturer, namely the student's mathematical literacy test assessment instrument and the instrument validation sheet assessment instrument. The validation process was carried out by providing an assessment of textbooks in terms of design and material, and a test instrument for students' mathematical literacy abilities. In the validation process, the validator provided suggestions or comments either in writing, orally, or through discussion activities. The results of the expert validation assessment by five validators are as in table 3 below:

Table 3: Score of Expert Validation Results on textbooks

\begin{tabular}{|c|c|c|c|c|c|}
\hline \multirow{2}{*}{ Product } & \multirow{2}{*}{$\begin{array}{l}\text { Score } \\
\text { Maks }\end{array}$} & \multicolumn{2}{|c|}{ Validator } & \multirow{2}{*}{ Average } & \multirow{2}{*}{$\begin{array}{l}\text { Asessment } \\
\text { Criteria }\end{array}$} \\
\hline & & 1 & 2 & & \\
\hline Textbook (in terms of Material Experts) & 145 & 115 & 116 & 115.5 & Valid \\
\hline Textbook (in terms of Design Experts) & 190 & 153 & 155 & 154 & Very Valid \\
\hline $\begin{array}{c}\text { Instrument for assessing students' } \\
\text { mathematical literacy skills }\end{array}$ & 55 & \multicolumn{2}{|c|}{45} & 45 & Very Valid \\
\hline
\end{tabular}

Table 3 above shows that the mathematics textbook is seen in terms of material, design, and mathematical literacy test instruments, all of which are very valid and valid in the assessment criteria. So it can be concluded that the textbooks and instruments developed in general are in the valid category.

\subsection{Expert Trial Data Analysis}

The data obtained from the validator were analyzed to determine the validity of the textbooks being developed. The data, the results of the validator's assessment of textbooks and the developed students' mathematical literacy test instruments, were analyzed. The validity of textbook products and instruments was determined by the maximum score and the conclusion from the validator's assessment. The results of the validation analysis of textbooks can be explained as follows:

\subsection{Analysis of Learning Textbook Validation Data}

The data from the validator's assessment of textbooks were the data from the analysis of the material expert validator's assessment, and the data for the analysis of the media expert's validator's assessment. The results of the textbook validation analysis were reviewed as a whole and based on each aspect of the assessment as in table 4 and table 5 as follows

Table 4. Results of Material Expert Validation Data Analysis in textbooks

\begin{tabular}{|c|c|c|c|c|c|}
\hline \multirow{2}{*}{ No } & \multirow{2}{*}{ Rated aspect } & \multicolumn{2}{|c|}{ Score Validator } & \multirow{2}{*}{ Average } & \multirow{2}{*}{ Criteria } \\
\hline & & 1 & 2 & & \\
\hline 1 & Suitability of Content and Material in textbooks & 28 & 26 & 27 & Valid \\
\hline 2 & Suitability of books based on Jambi culture & 25 & 23 & 24 & Valid \\
\hline 3 & $\begin{array}{l}\text { Suitability of books to measure mathematical } \\
\text { literacy skills }\end{array}$ & 20 & 22 & 21 & Very Valid \\
\hline 4 & Benefits / uses of textbooks & 23 & 25 & 24 & Valid \\
\hline 5 & Language suitability in textbooks & 19 & 20 & 19,5 & Valid \\
\hline & Total & 115 & 116 & 115,5 & Valid \\
\hline
\end{tabular}


Table 5. Results of Design Expert Validation Data Analysis in Textbooks

\begin{tabular}{|c|l|c|c|c|c|}
\hline \multirow{2}{*}{ No } & \multicolumn{1}{|c|}{ Rated aspect } & \multicolumn{2}{c|}{$\begin{array}{c}\text { Score } \\
\text { Validator }\end{array}$} & \multirow{2}{*}{ Average } & Criteria \\
\cline { 3 - 6 } & & 1 & 2 & & \\
\hline 1 & Content coverage provisions & 28 & 32 & 30 & Valid \\
\hline 2 & Overall display compatibility & 35 & 35 & 35 & Valid \\
\hline 3 & $\begin{array}{l}\text { The suitability of the aspects of textbook } \\
\text { emphasis on Javanese culture }\end{array}$ & 32 & 30 & 31 & very Valid \\
\hline 4 & $\begin{array}{l}\text { The suitability of the aspects of choosing } \\
\text { shapes, textures, and colors }\end{array}$ & 28 & 30 & 29 & very Valid \\
\hline 5 & Eligibility of the language used & 30 & 28 & 29 & very Valid \\
\hline \multicolumn{2}{|c|}{ Total } & 153 & 155 & 154 & very Valid \\
\hline
\end{tabular}

Based on table 4 and table 5, the results of the material expert and design expert validation sheet analysis of textbooks indicate that the book is ready for use or suitable for use at the limited trial stage and in valid categories / criteria. The suggestions for improvement given by the validator after several stages of revision can generally be seen in the following figure:
1. Comments and suggestions for improvement from the 2 expert design validators

Comments and suggestions for improvement from the 2 design validators are presented in Figure 1 .

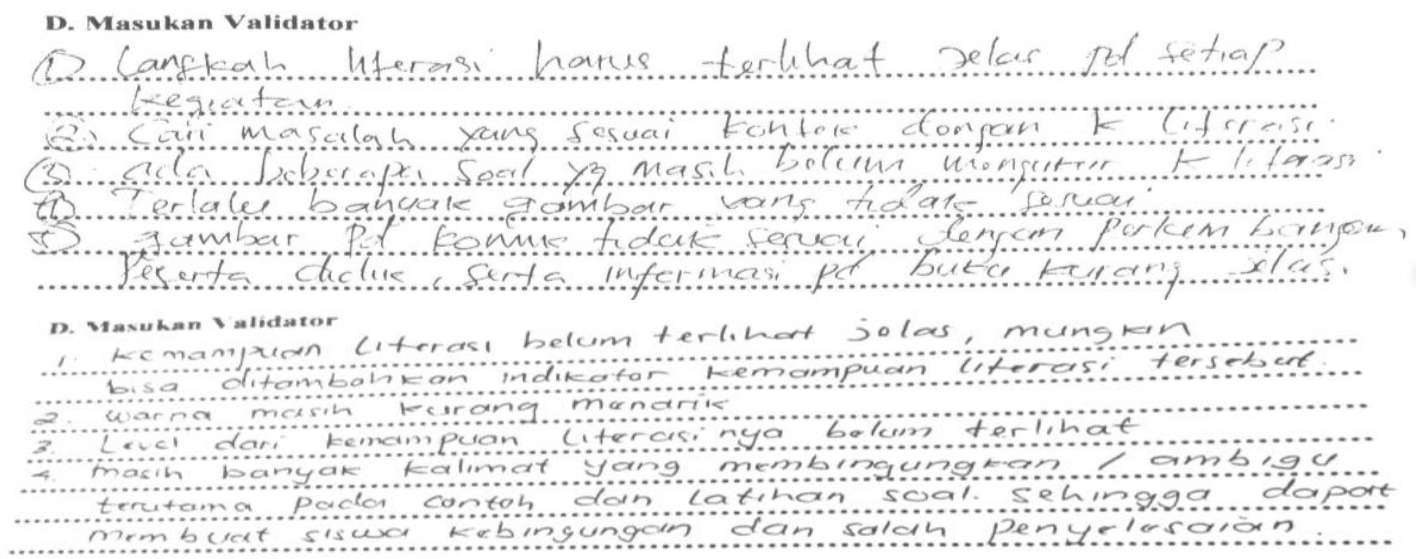

Figure 1. Comments and Improvement Suggestions from the 2 Design Validators

Based on suggestions and comments from design expert validators, both in written and oral that the validator suggests giving; (1) The steps to measure literacy skills in each learning activity are not yet clear; (2) The characteristics of his mathematical literacy skills must be clearly visible; (3) Improve the presentation of contextual problems to become "problems" in accordance with mathematical literacy skills in learning activities; (4) Every problem solving, such as sample questions, exercises contain indicators of literacy skills; (5) The use of image icons in textbooks in presenting the problem is still not neat or mostly ambiguous; (6) The students' mathematical literacy skills have not been seen at each level; (7) The background is still monotonous and the colors on the writing, the supporting images are less attractive and not cropped; (8) the information in the book is still not clear; The suggestions and comments from the Expert validator (design) have been revised.

2. Comments and suggestions for improvement from the 2 material expert validators

Comments and suggestions for improvement from the 2 material expert validators are presented in Figure 2.

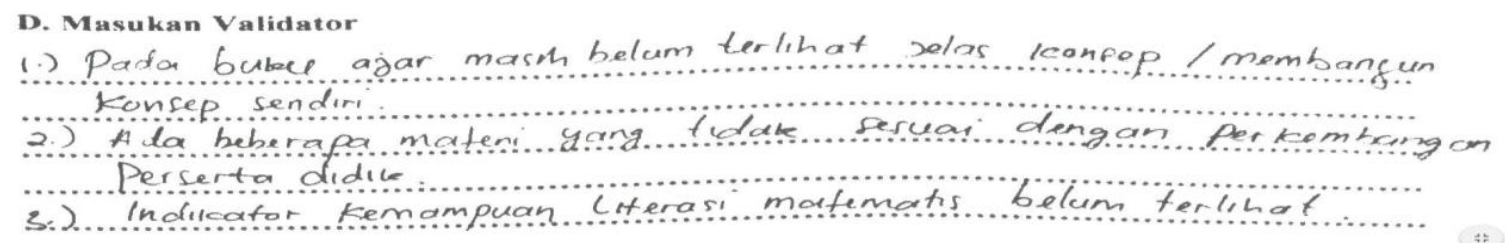




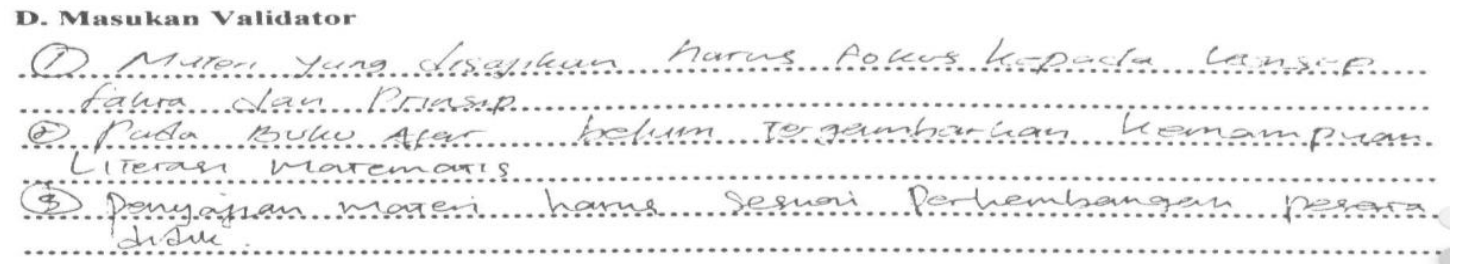

Figure 2. Comments and Improvement Suggestions from the 2 validator material experts

Based on suggestions and comments from material expert validators, both in written and oral that the validator suggests giving; (1) The developed textbook is not clear about the problems that can develop its own concept; (2) The material presented must focus on concepts, facts, and principles; (3) The delivery of material in textbooks has not shown an indicator of mathematical literacy skills; (4) The material presented must be in accordance with the development of students.

\subsection{Analysis of Assessment Instrument Data}

The data for the assessment of students' mathematical literacy abilities test from the validator were analyzed to determine its validity. The assessment data from the validator are valid and invalid criteria. The results of the data analysis of the validation of students' mathematical literacy skills are as shown in table 6 as follows:

Table 6. Results of Data Validation Analysis of Students' Mathematical Literacy Ability Assessment Tests

\begin{tabular}{|c|c|c|c|}
\hline No & Rated aspect & $\begin{array}{c}\text { Score } \\
\text { Validator }\end{array}$ & Criteria \\
\hline 1 & The suitability of the questions with the material & 12 & Valid \\
\hline 2 & Language Eligibility & 8 & Valid \\
\hline 3 & Construction instructions & 8 & Valid \\
\hline 4 & $\begin{array}{c}\text { Problem Measuring students' mathematical } \\
\text { literacy skills }\end{array}$ & 17 & very Valid \\
\hline & Total & 45 & very Valid \\
\hline
\end{tabular}

Based on table 6 above, it shows that the instrument for assessing students' mathematical literacy skills developed is included in the valid category. The results of the validation analysis show that the suggestions for improvement focus on the problem editor, the use of verbs on the indicators, the selection of the question editor for students' mathematical literacy abilities. In general, the suggestions given by the validator after carrying out several stages of revision are as shown in Figure 3 as follows:

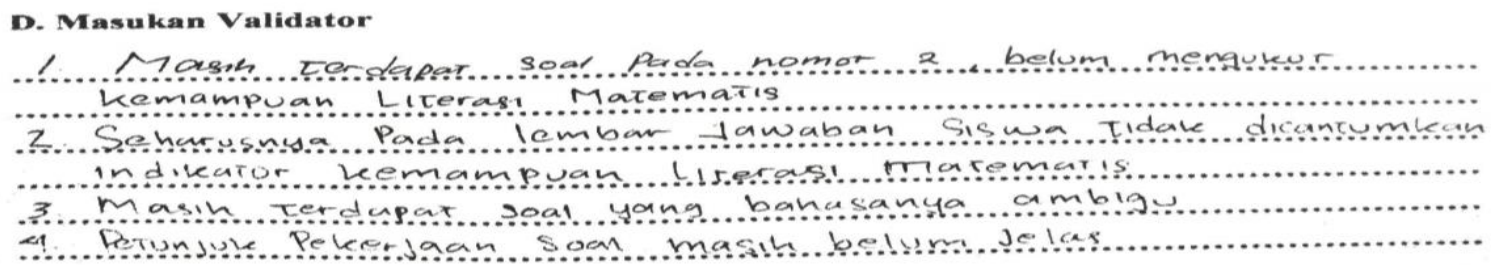

Figure 3. Suggestions for Improvements to Students' Mathematical Literacy Ability Test Instruments by Validators

Based on Figure 3, it is obtained suggestions and comments from the instrument expert validator, both in written and oral that the validator suggests giving; (1) There is still one question that has not measured students' mathematical literacy skills; (2) On the student answer sheet, written indicators of students' mathematical literacy abilities should not be mentioned; (3) There is one question whose language is ambiguous, so it can make students misinterpretation; (4) The job instructions for the question are still not clear. The suggestions and comments from the Material Expert validator have been revised.

\section{DISCUSSION}

At the analysis stage with several steps carried out, it aims to analyze what needs students require to achieve curriculum goals that are tailored to the characteristics of students, initial abilities and prerequisite abilities, as well as how the students' learning environment is. After the analysis stage was carried out, the design stage was carried out, namely designing the developed textbook. In this design stage, there were several steps taken, namely: 1) Determining the development team, 2) Determining the required resources, 3) Developing a development 
schedule, 4) Selecting and determining the scope, structure and sequence of learning materials or messages, 5) Making storyboards, 6) Determining product specifications, 7) Making product prototypes. Furthermore, the development stage was carried out which consisted of 2 steps, namely validation of experts and validation of practitioners. After the development stage, then the disseminate stage. Textbooks developed to be used as supporting material during learning. Textbooks as teaching materials are very necessary in the learning process because they can affect the quality of learning [10]

The validation results of the textbooks from the 2 material experts each got a value of $79.31 \%$ and $80 \%$, which means that the textbook developed has met the valid criteria. Even though the textbook is said to be valid, there are still improvements / revisions suggested by the 2 validators so that the material presented in the book becomes more systematic and meaningful. This is in line with his opinion [11] that the material in teaching materials should be arranged systematically / directed from simple material to complex material.

The results of the textbook validation from the 2 design experts each got a value of $80.53 \%$ and $81.58 \%$, which means that the textbook developed has met the very valid criteria. Textbooks that have been said to be valid by design experts, still have a few revisions suggested by design experts. The revision is related to the accuracy in designing a teaching material. This is in line with the opinion of Suparti, et al [12] that media expert validators help validate the accuracy of designing teaching materials, if there are teaching materials that are not quite right, they can be corrected again. Design expert validators can assess textbooks in terms of color, letters, font size, illustrations, accuracy of components and others, so as to attract students' attention to open and read them [13]. Learning objectives will be maximally achieved with textbooks, textbooks must have complete components along with examples of questions and answers [14][15][16].

\section{CONCLUSION}

The validators in this study were five validators / experts, namely 2 Design Expert validators, 2 Material Expert Validators in the developed textbooks and 1 validator regarding the research instrument. This learning textbook meets the valid criteria, where the validation of the material expert on the learning textbook each gets a score of 115 out of 145 (maximum score), 116 from (maximum score) and the average percentage score of the validation results from material experts is $79.31 \%$ and $80 \%$. Validation from design experts on textbooks obtained scores / values, namely 153 out of 190 (maximum score) and 155 out of 190 (maximum score) and the percentage of mean scores obtained from design experts is $80.53 \%$ and $81.58 \%$. As well as the validation of the instrument expert gets a score / value of 45 out of 55 (maximum score), with the percentage value of the results of the instrument expert being $81.82 \%$. Therefore, it can be concluded that the developed mathematics learning textbook meets valid criteria and can be used for the next stage.

\section{REFERENCES}

[1] Syahlan. (2015). Literasi Matematika Dalam Kurikulum 2013. 3(1): 36 - 43. ISSN (Print) : 23376198 ISSN (Online) : 2337-618X

[2] B. Hayat, \& S. Yusuf. (2010). Benchmark Internasional Mutu Pendidikan. Jakarta: Bumi Aksara.

[3] OECD. (2016). PISA 2015: Assessment and Analytical Framework Science, Reading, Mathematic and Financial Literacy. Kanada: OECD.

[4] Abidin, et al. (2017). Pembelajaran Literasi. Jakarta: Bumi Aksara

[5] Khikmiyah, Fatimatul \& Midjan. 2016. "Pengembangan Buku Ajar Literasi Matematika untuk Pembelajaran di SMP”. Jurnal Silogisme: Kajian Ilmu Matematika dan Pembelajarannya. Universitas Muhammadiyah Gresik

[6] U. Hasanah, W. Wardono, \& K. Kartono, (2016). Keefektifan Pembelajaran MURDER Berpendekatan PMRI dengan Asesmen Kinerja Pada Pencapaian Kemampuan Literasi Matematika Siswa SMP Serupa PISA. Unnes Journal of Mathematics Education, 5(2)

[7] B. Ojose. (2011). Mathematics Literacy: Are We Able To Put The Mathematics We Learn Into Everyday Use? Journal of Mathematics Education. Vol 4, No. 1, p 89-100,

[8] OECD. (2018). PISA for Development Assessment and Analytical Framework: Reading, Mathematics and Science. Paris: OECD Publishing.

[9] Riduwan. 2015. Dasar-dasar Statistik. Bandung : Alfabeta

[10] M. Arsanti.. (2018). Pengembangan Bahan Ajar Matakuliah Penulisan Kreatif Bermuatan NilaiNilai Pendidikan Karakter Religius bagi Mahasiswa Prodi PBSI, FKIP, Unisula. Kredo: Jurnal Ilmiah Bahasa dan Sastra, 1(2), 71-90. DOI: https://doi.org/10.24176/kredo.v1i2.2107

[11] Salim. (2016). Pengembangan Bahan Ajar Matematika Berbantuan Software Drive untuk Meningkatkan Kemampuan Berpikir Kritis 
Matematis Siswa Kelas X1 IPA SMA Negeri 1 Pasarwajo. Indonesian Digital Journal of Mathematics and Education, 3(4), 199-207

[12] Suparti., I. Wiryokusumo, \& D. Adiwalujo. (2015). Pengembangan Bahan Ajar Ilmu Pengetahuan Alam (Biologi) Berbasis Web dengan Pendekatan Jigsaw untuk Siswa Sekolah Menengah Pertama Kelas VIII. Jurnal Teknologi Pembelajaran Devosi, 5(2), $138-150$.

[13] I. Oktaviana, S. B. Sumitro, \& U. Lestari. (2015). Pengembangan Bahan Ajar Berbasis Penelitian Karakterisasi Protein Membran Sperma pada Matakuliah Bioteknologi. Florea: Jurnal Biologi dan Pembelajarannya, 2(2), 33-42. http://doi.org/10.25273/florea.v2i2.413

[14] I. Lestari, (2013). Pengembangan Bahan Ajar Berbasis Kompetensi. (Sesuai dengan Kurikulum Tingkat Satuan Pendidikan). Padang: Akademia Permata.

[15] A. Prastowo. (2015). Panduan Kreatif Membuat Bahan Ajar Inovatif. Yogyakarta: DIVA Press.

[16] J. Mbulu, \& Suhartono. (2004). Pengembangan Bahan Ajar. Malang: Elang Mas. 